\title{
Effects of temperature, sestonic algae features, and seston mineral content on cladocerans of a tropical lake
}

\author{
Cláudia Fileto $^{1 *}$, Marlene Sofia Arcifa ${ }^{2}$, Raoul Henry ${ }^{1}$ and Rosa A.R. Ferreira ${ }^{1}$ \\ ${ }^{1}$ Departamento de Zoologia, Instituto de Biociências, Unesp, Campus Botucatu, Rubião Jr., s/nº, 18618-000 Botucatu, \\ São Paulo, Brazil \\ ${ }^{2}$ Faculdade de Filosofia, Ciências e Letras de Ribeirão Preto, Departamento de Biologia, Universidade de São Paulo, Avenida \\ Bandeirantes, 3900, 14040-901 Ribeirão Preto, São Paulo, Brazil
}

Received 7 November 2009; Accepted 25 January 2010

\begin{abstract}
The effects of temperature on the life table, and of seston quality on the individual growth and reproduction of cladocerans from a tropical lake were tested in the laboratory. Life-table experiments were carried out at $17^{\circ} \mathrm{C}, 23{ }^{\circ} \mathrm{C}$, and $27^{\circ} \mathrm{C}$. Growth bioassays tested the influence of natural seston fractions, separated by net filtration, on cladocerans. The treatments were: (1) total seston plus Scenedesmus spinosus $\left(1 \mathrm{mg} \mathrm{C.L}{ }^{-1}\right)$, (2) seston $\leq 36 \mu \mathrm{m}$, and (3) seston $>36 \mu \mathrm{m}$. Phytoplankton composition, density, and biomass were evaluated during growth experiments, together with sestonic carbon, nitrogen, and phosphorus concentrations. The intrinsic rates of natural increase were higher for Moina micrura and Daphnia ambigua at $27^{\circ} \mathrm{C}$ compared to $17^{\circ} \mathrm{C}$. The age at first reproduction of both species was delayed at $17^{\circ} \mathrm{C}$. Growth rates and fecundity of $M$. micrura were higher in the seston fraction $\leq 36 \mu \mathrm{m}$ than in the fraction $>36 \mu \mathrm{m}$. Higher growth rates and fecundity of Moina minuta were observed in the seston enriched with the green alga in comparison to the seston $\leq 36 \mu \mathrm{m}$ and $>36 \mu \mathrm{m}$. Bosmina longirostris was unable to reproduce at $17^{\circ} \mathrm{C}$ and to grow in the seston $>36 \mu \mathrm{m}$ in one experiment. High densities and/or biomass of large colonial and filamentous algae present in the larger seston fraction could have contributed to reduce growth and reproduction. Episodes of food-quantity limitation may occur, but there was no evidence of mineral limitation, although seston $\mathrm{C}: \mathrm{P}$ and $\mathrm{C}: \mathrm{N}$ ratios were always above the limiting values assumed for temperate water bodies. The $\mathrm{C}: \mathrm{P}$ and $\mathrm{C}: \mathrm{N}$ ratios are highly influenced by carbon that originates primarily from resuspended detritus from the lake.
\end{abstract}

Key words: Food size / nitrogen / phosphorus / seston / temperature / tropical cladocerans

\section{Introduction}

Lakes connected to rivers are subject to flood pulses, and zooplankton peaks occur during high- or low-water phases (Talling and Lemoalle, 1998; Martins and Henry, 2004; Granado and Henry, 2008). The factors controlling zooplankton populations in such disturbed lakes with variable water levels and external influences are complex. Hydrological variations are of prime importance in floodplains and wetlands, and can determine zooplankton structure and dynamics (Panarelli et al., 2003; Choueri et al., 2005). Hydrological pulses can influence the primary producers in floodplain lakes, directly or indirectly affecting the entire food web.

\footnotetext{
*Corresponding author: cfileto@hotmail.com
}

The depth limit of a "shallow lake" is not easily defined (Padisák and Reynolds, 2003). Functionally, the criterion for defining shallowness is frequent mixing, with consequent sediment resuspension. In many shallow lakes, inorganic particles and algal cells have a rapid cycle of sedimentation and resuspension (Scheffer, 2004). Deep lakes can be differentiated by their longer stratification periods, and their lower turbidity favors primary production. Light is limiting for the photosynthetic process in the hypolimnion, where nutrients are trapped, declining in the euphotic zone.

Lake Camargo fits the definition of a shallow lake, being less than $5 \mathrm{~m}$ deep and experiencing frequent mixing (Padisák and Reynolds, 2003), and besides, it is influenced by the river to which it is connected (Henry, 2005). Because it is a tropical lake, the annual variation of temperature is relatively narrow and biotic interactions are 
intense along the year, zooplanktonic populations being in continuous reproduction. Studies on floodplains are numerous, but not on lakes located at the confluence of rivers and reservoirs (Luciano and Henry, 1998).

Temperature and food quantity and quality in terms of mineral, biochemical, and algae morphology are among the most important factors that influence zooplankton growth and life-table parameters (e.g. Bottrell, 1975; Vijverberg, 1980; Gulati and DeMott, 1997; Lennon et al., 2001; Acharya et al., 2004; Hessen, 2006, 2008; Ravet and Brett, 2006; Martins-Creuzburg et al., 2009; Seinderdorf et al., 2010).

Several studies on zooplankton have been carried out in Lake Camargo and in two other lakes of the Paranapanema River (Panarelli et al., 2003; Casanova and Henry, 2004; Martins and Henry, 2004; De Nadai and Henry, 2009). However, laboratory tests of hypotheses regarding interactions between planktonic herbivores and abiotic factors and food quality were lacking.

The present study aimed to fill this gap by testing the effects of different temperatures on some life-table parameters of three cladoceran species, as well as the influence of features of sestonic algae (size, shape, presence of spines, and gelatinous sheaths) on the growth and reproduction of cladocerans of different sizes. Algae mineral content and other carbon sources were evaluated in the lake by analyzing the sestonic particulate organic carbon (POC), phosphorus, and nitrogen concentrations, and the $\mathrm{C}: \mathrm{P}$ and $\mathrm{C}: \mathrm{N}$ ratios, during one year. Phytoplankton composition, density, biomass, and algae contribution to POC were evaluated in order to assess the influence of algae features and carbon sources other than algae on cladocerans.

\section{Materials and methods}

\section{Study area}

Lake Camargo (23 $30^{\prime} 10^{\prime \prime} \mathrm{S}$ and $\left.48^{\circ} 42^{\prime} 35^{\prime \prime} \mathrm{W}\right)$ is a lake located near the confluence of the Paranapanema River and the Jurumirim Reservoir, in the state of São Paulo, southeastern Brazil. The lake is permanently connected to the river except during long dry periods, such as from October 1999 to December 2000 (Henry, 2005), and in occasional episodes, for example from August 2006 to January 2007. It is a shallow (max. depth $=3.9 \mathrm{~m}$; mean depth $=3.2 \mathrm{~m}$ ), continuous polymictic lake with microstratifications in the afternoon and isothermy in the morning (Moschini-Carlos et al., 1999), indicating that it circulates at night due to its shallowness and to wind action. Resuspension of sediment contributes most of the suspended matter to the lake, and the river contributes a small amount of sediment $(1 \%$ of its total load) (Henry, 2009). Total nitrogen and phosphorus ranged from 63-411 $\mu \mathrm{g} . \mathrm{L}^{-1}$ and from $13-63 \mu \mathrm{g} . \mathrm{L}^{-1}$, respectively, in the upper layers during 2002-2003. The phytoplankton is primarily composed of Cryptophyceae (Chroomonas spp. and Cryptomonas brasiliensis), followed by Chlorophyceae and Bacillariophyceae (Henry et al., 2006), at densities ranging from 435 to 7710 ind. $\mathrm{mL}^{-1}$. Ceriodaphnia cornuta Sars fa. rigaudi and Diaphanosoma birgei Korineck were recorded in every month in the lake from 2000 to 2001. Bosminopsis deitersi Richard, Bosmina hagmanni Stingelin, and Moina minuta Hansen can also reach high abundances (Panarelli, 2004). The production of Bosmina longirostris (O. F. Müller), D. birgei, and C. c. rigaudi, in January 2001 (wet-warm season), was respectively 6050, 22020, and $2048 \mu \mathrm{g} \mathrm{DW} . \mathrm{m}^{-3}$.day ${ }^{-1}$; and in July 2001 (cool-dry season) 391.9, 517.2, and $1.1 \mu \mathrm{g} \mathrm{DW} . \mathrm{m}^{-3}$.day ${ }^{-1}$, respectively. The region has two seasons, cool-dry (April to October) and warm-wet (November to March).

\section{Algae and cladoceran cultures}

The chlorophycean Scenedesmus spinosus R. Chodat (length $14 \mu \mathrm{m}$ ) was used as food for cladocerans. It was grown in batch cultures using MBL medium (Stemberger, 1981 ) in an environmental chamber (Eletrolab-model $100 \mathrm{G})$ with constant aeration and temperature $\left(23^{\circ} \mathrm{C}\right)$, and a 12:12 h dark/light photoperiod.

The cladocerans used in all the experiments were collected in Lake Camargo, with a $50 \mu \mathrm{m}$-mesh net, by vertical hauls through the entire water column. The species were separated under a stereomicroscope and cultured in the laboratory in $600 \mathrm{~mL}$-beakers containing filtered lake water (glass fiber filters - Millipore AP 40) plus $1 \mathrm{mg} . \mathrm{L}^{-1}$ of S. spinosus. The animals were cultured for several generations prior to the experiments, at constant temperature $\left(23^{\circ} \mathrm{C}\right)$ and a $12: 12 \mathrm{~h}$ dark/light photoperiod.

\section{Life-table experiments testing the effect of temperature on cladocerans}

Four experiments on the life cycle of cladocerans were carried out, at the following temperatures: $17^{\circ} \mathrm{C}(18 / \mathrm{I}-22 /$ II $/ 06$, and $15 / \mathrm{V} / 08-03 / \mathrm{VI} / 08$, only for $B$. longirostris), $27^{\circ} \mathrm{C}(28 / \mathrm{III}-03 / \mathrm{V} / 06)$, and $23^{\circ} \mathrm{C}(23 / \mathrm{IV}-31 / \mathrm{V} / 06)$. These temperatures have been chosen because they represent the minimum $\left(17^{\circ} \mathrm{C}\right)$, the maximum $\left(27^{\circ} \mathrm{C}\right)$, and the intermediate $\left(23^{\circ} \mathrm{C}\right)$ values in the lake during the year.

The cladocerans used in the experiments were Daphnia ambigua Scourfield (maximum length $0.90 \mathrm{~mm}$ ), Moina micrura Kurz (max. length $0.85 \mathrm{~mm}$ ), Moina minuta Hansen (max. length $0.70 \mathrm{~mm}$ ), and Bosmina longirostris (max. length $0.40 \mathrm{~mm}$ ). The choice of species for the experiments was based on previous studies on the temporal distribution of cladocerans, and their appearance in the lake during the experiments as well.

One day prior to the experiments, ovigerous females from the laboratory cultures were placed in $600-\mathrm{mL}$ beakers containing filtered lake water (glass fiber filters - Millipore AP 20) and $1 \mathrm{mg} \mathrm{C.L^{-1 }}$ of the chlorophycean Scenedesmus spinosus. Ten neonates (born within $24 \mathrm{~h}$ ) were placed in individual assay tubes containing 
$30 \mathrm{~mL}$ of filtered lake water and $1 \mathrm{mg} \mathrm{C} . \mathrm{L}^{-1}$ of $S$. spinosus. The animals were transferred daily to new algae suspensions, and the number of survivors and of neonates produced were counted to calculate the survivorship $(l x)$ and fecundity $(m x)$.

The intrinsic rate of natural increase $(r)$ for each species was estimated by considering all individuals tested in each temperature as a cohort (Andersen and Benke, 1994). The calculated parameters were the net reproductive rate, the mean generation time, and $r$, according to the formulae found in Gotelli (1995). Ten replicates were carried out for each treatment (temperature), and the experiments ended when the last individual died. The $r$ and $G$ values were compared using Student's $t$ test. Population parameters, calculated from life-table data, included the age at first reproduction (appearance of eggs in the brood chamber), maximum clutch size, mean fecundity, total of neonates produced/female, and longevity. ANOVA was used to test for the main effects of species, treatments, and the interaction between these two factors. Differences between treatments for each species were tested using multiplecomparison Tukey tests $(P<0.05)$.

\section{Growth experiments testing the quality of food}

\section{Seston suspension preparations, elemental and phytoplankton analyses}

During the experiments, the natural seston offered as food for cladocerans was collected in the water column of the lake, using a motorized pump (Stihl P 835). Each time that the water in the experimental vessels was renewed, five liters of lake water were filtered through a $140-\mu \mathrm{m}$ net to exclude large zooplankton. Then, the water was filtered through a $36-\mu \mathrm{m}$ net, separating the fraction $\leq 36 \mu \mathrm{m}$ in the filtrate; the larger fraction retained in the net was resuspended in filtered lake water. The filtration was carried out without pumping, filtering two liters at a time and then stopping to clean the nets to avoid clogging.

Aliquots of total and seston fractions used in the experiments were taken for chemical analyses, to separate food quantitative effects (carbon content) from qualitative effects (phosphorus and nitrogen content). Samples (200-400 mL) were filtered through pre-ignited glass-fiber filters (Millipore AP 40) for analyses of particulate organic carbon (POC), phosphorus (P), and nitrogen (N). POC was analyzed according to Strickland and Parsons (1972), $\mathrm{P}$ by the molybdate method (Murphy and Riley, 1962), and nitrogen by the classic Kjeldahl method (Mackareth et al., 1978).

To investigate the annual variation of sestonic particulate organic carbon, phosphorus, and nitrogen contents, the seston was sampled once a month, during one year (November 2005-November 2006), integrating the water column, using a motorized pump. The water was filtered in a $140-\mu \mathrm{m}$ net to exclude large zooplankton and then in a $36-\mu \mathrm{m}$ net. Aliquots of $200-400 \mathrm{~mL}$ from the filtrate were then filtered in pre-ignited glass-fiber filters (Millipore AP 40), before the determinations of POC, P, and N. A size limit of $36 \mu \mathrm{m}$ was assumed, because it is similar to the algal edibility value of $35 \mu \mathrm{m}$ found in the literature (Burns, 1968; Vanni, 1987). Suspended matter was determined by the gravimetric method (Cole, 1979), weighing the same filters used for the chemical analyses.

Phytoplankton composition and abundance were evaluated during the experiments, and the mean values of the most abundant species were used in this study. Phytoplankton was counted under an inverted microscope (Leica) according to Utermöhl's (1958) method. The carbon content of the algae was assumed to be $10 \%$ of their wet weight (Vollenweider, 1974), for evaluating their relative contribution to the fractions. Morphological features of the algae, including size, shape, and the presence of hard cell walls and gelatinous sheaths were also analyzed. Algae species in the phytoplankton fractions were represented as $\%$ of density and biomass.

\section{Growth bioassays}

These experiments were carried out from 19 to 24/V/2006 (Experiment I) and from 23 to $27 / \mathrm{X} / 2007$ (Experiment II), under controlled temperature $\left(24^{\circ} \mathrm{C}\right)$ and a 12:12 $\mathrm{h}$ light/dark photoperiod, using the cladocerans Bosmina longirostris, Moina micrura, and M. minuta from laboratory cultures. About seven individuals, born within $24 \mathrm{~h}$, were placed in 100-mL stoppered bottles, attached to a plankton wheel, rotating for 1 minute every 15 minutes. The treatments, with three replicates each, were: (1) total seston enriched with Scenedesmus spinosus (1 mg C. $\left.\mathrm{L}^{-1}\right)$, (2) seston $\leq 36 \mu \mathrm{m}$, and (3) seston $>36 \mu \mathrm{m}$

At the beginning of the experiments, three groups of 10 neonates, born within $24 \mathrm{~h}$, were placed on a glass slide, dried at $60^{\circ} \mathrm{C}$ overnight, and weighed on a microbalance (Mettler Toledo UMT-2) to determine the initial body weight (mean of the three groups of ten neonates). Seven neonates, born within $24 \mathrm{~h}$, were placed in each of three separate $100-\mathrm{mL}$ stoppered bottles (three replicates) for each treatment. The animals were transferred every other day to new seston suspensions. The experiment lasted until the first eggs were produced, when the animals were measured, placed on slides, dried at $60^{\circ} \mathrm{C}$ overnight, and weighed. The average individual biomass was obtained for the animals caught in the three bottles. The exponential growth rate was calculated by the equation: $g=\left[\ln \left(W_{t}\right)-\right.$ $\left.\ln \left(W_{0}\right)\right] / t$, where: $W_{0}$ and $W_{t}$ are the average weights of the animals at time 0 and after $t$ days (3-5 days, depending on the juvenile period of each species), respectively. The fecundity (eggs/total female) was calculated at the end of the experiments by counting the eggs in the female brood chamber. Results were analyzed using ANOVA (Statistica Program) to test for the main effects of species, treatments, and the interaction between these two factors. Differences between treatments for each species were tested using multiple-comparison Tukey tests $(P<0.05)$. 


\section{Results}

\section{Field data}

The suspended-matter concentrations of the seston fraction $\leq 36 \mu \mathrm{m}$ oscillated during the year without, however, exhibiting a clear seasonality. A peak in May 2006 (30 mg. $\mathrm{L}^{-1}$ ) was followed by a decrease to the lowest value in July 2006 (3.85 mg. $\mathrm{L}^{-1}$ ) (Fig. 1). Annual sestonic POC concentrations ranged from 4.20 to $10.40 \mathrm{mg} . \mathrm{L}^{-1}$; the higher levels occurred after the lake became isolated from the river, from August 2006 to January 2007 (R.C. Mortari, unpublished data), when it was very shallow. $\mathrm{N}$ and $\mathrm{P}$ sestonic concentrations varied between 90 and $370 \mu \mathrm{g} . \mathrm{L}^{-1}$ and 8.20 and $36 \mu \mathrm{g} . \mathrm{L}^{-1}$, respectively. $\mathrm{C}: \mathrm{P}$ and $\mathrm{C}: \mathrm{N}$ ratios were always higher than the limiting concentrations assumed for temperate lakes (300 and 15, respectively). Higher values of $\mathrm{C}: \mathrm{P}$ were found in the cooldry season, and of $\mathrm{C}: \mathrm{N}$ in May and from September to November (the dry season and the beginning of the wet season).

The depth varied from $0.87 \mathrm{~m}$, in November 2006, to $3.70 \mathrm{~m}$ in May (R. Henry, unpublished data), reflecting the effect of seasonal hydrological pulses. Experiment I was undertaken during a deeper phase of the lake (May 2006). Experiment II was carried out (October 2007) when it was very shallow $(0.87 \mathrm{~m})$.

During Experiment I, the phytoplankton was mostly composed of Bacillariophyceae, Chlorophyceae, Cryptophyceae, Chrysophyceae, and Cyanophyceae (Fig. 2). Large diatoms predominated in density, and a large colonial chlorophycean (Botryococcus braunii) in biomass (Table 1). During Experiment II, the phytoplankton was largely dominated by Cryptophyceae, followed by Bacillariophyceae and Crysophyceae. Small nanoplanktonic cryptophyceans predominated in density and biomass (Table 1).

\section{Experiments on the effect of temperature}

\section{Intrinsic rate of natural increase (r)}

The intrinsic rate of natural increase $(r)$ of $M$. micrura was higher at $27^{\circ} \mathrm{C}$ than at the lower temperatures $\left(23^{\circ} \mathrm{C}\right.$ and $\left.17^{\circ} \mathrm{C}\right)(P=0.002$ and 0.005 , respectively). The same occurred with $D$. ambigua $(P=0.000$ and $P=0.049$, respectively) (Table 2). Differences between $r$ at the two lower temperatures, for both species, were not significant. $B$. longirostris responded similarly to the former species, with a higher $r$ at $27^{\circ} \mathrm{C}$ than at $23^{\circ} \mathrm{C}(P=0.002)$. This species was unable to reproduce at $17^{\circ} \mathrm{C}$, precluding $r$ calculation.

\section{Life-table parameters}

The three cladocerans experienced a delay of the age at first reproduction at the lower temperatures (Table 2). The maturation of $M$. micrura was delayed at $17^{\circ} \mathrm{C}$ in comparison to $23{ }^{\circ} \mathrm{C}(P=0.005)$ and $27^{\circ} \mathrm{C}(P=0.003)$; there was no significant difference in maturation time between the intermediate and high temperatures. Similarly, D. ambigua also showed a delay of the onset of reproduction at the lowest temperature compared to the highest and the intermediate temperatures $(P=0.000$ and $P=0.003$, respectively). The reproduction of $B$. longirostris was delayed at $23{ }^{\circ} \mathrm{C}$ compared to $27^{\circ} \mathrm{C}$ $(P=0.002)$. A shorter longevity at $27^{\circ} \mathrm{C}$ in relation to the other temperatures was a general trend for two of the three species. At the highest temperature, the longevity of $M$. micrura was reduced to half of that at the lower temperatures $(P=0.031$ for both). The longevity of B. longirostris was ca. $40 \%$ shorter at $27^{\circ} \mathrm{C}$ compared to $23{ }^{\circ} \mathrm{C}(P=0.000)$. The fecundity and the maximum clutch size did not differ with temperature for the three species (Table 2).

The total neonates produced during the lifetime varied depending on the species. D. ambigua produced more neonates at $27^{\circ} \mathrm{C}$ than at $17^{\circ} \mathrm{C}(P=0.002)$ and $23^{\circ} \mathrm{C}$ $(P=0.004)$. The total number of neonates of $M$. micrura was higher at the intermediate temperature than at the lowest one $(P=0.040)$. There was no significant difference in the number of neonates produced by $B$. longirostris at $23^{\circ} \mathrm{C}$ and $27^{\circ} \mathrm{C}$.

There was a tendency for two cladocerans to have more clutches at the highest temperature. Four clutches were produced by $M$. micrura at $17^{\circ} \mathrm{C}$ and seven at the other temperatures (Fig. 3). The number of neonates in the first and third clutches was, however, larger at $17^{\circ} \mathrm{C}$ than at $23{ }^{\circ} \mathrm{C}(P=0.000$ and $P=0.030$, respectively $)$, and that of the first clutch at $27^{\circ} \mathrm{C}(P=0.000)$; the fourth clutch was smaller at $27^{\circ} \mathrm{C}$ compared to $23^{\circ} \mathrm{C}(P=0.015)$. Eight clutches were produced by $D$. ambigua at the lowest temperature, and ten and fifteen, respectively, at the intermediate and the highest ones. The second clutch was larger at $23{ }^{\circ} \mathrm{C}$ compared to $27^{\circ} \mathrm{C}(P=0.002)$, and the seventh one larger at $17^{\circ} \mathrm{C}$ than at $27^{\circ} \mathrm{C}(P=0.03)$. In contrast to the other two species, the number of clutches of $B$. longirostris was smaller (4) at the highest temperature in comparison to the intermediate one (7). Only the second clutch was slightly larger at $27^{\circ} \mathrm{C}(P=0.008)$.

\section{Experiments on the influence of food quality}

\section{Growth bioassays}

The growth rate of $M$. micrura was higher in the fraction $\leq 36 \mu \mathrm{m}(0.10)$ compared to the fraction $>36 \mu \mathrm{m}$ $(P=0.035)$ in Experiment I (Fig. 4). In contrast, there was no statistical difference between the growth rates of $B$. longirostris in the treatments $\leq 36 \mu \mathrm{m}$ and $>36 \mu \mathrm{m}$. In Experiment II, M. minuta showed a higher growth rate in the seston plus the green alga (0.50) than in the seston fractions $\leq 36 \mu \mathrm{m}(0.11)$ and $>36 \mu \mathrm{m}(0.08)(P=0.000)$. A significantly higher growth rate of $B$. longirostris was found in the treatment $\leq 36 \mu \mathrm{m}(0.60)$ than in the seston plus the green alga $(0.24)(P=0.000)$, in Experiment II; 

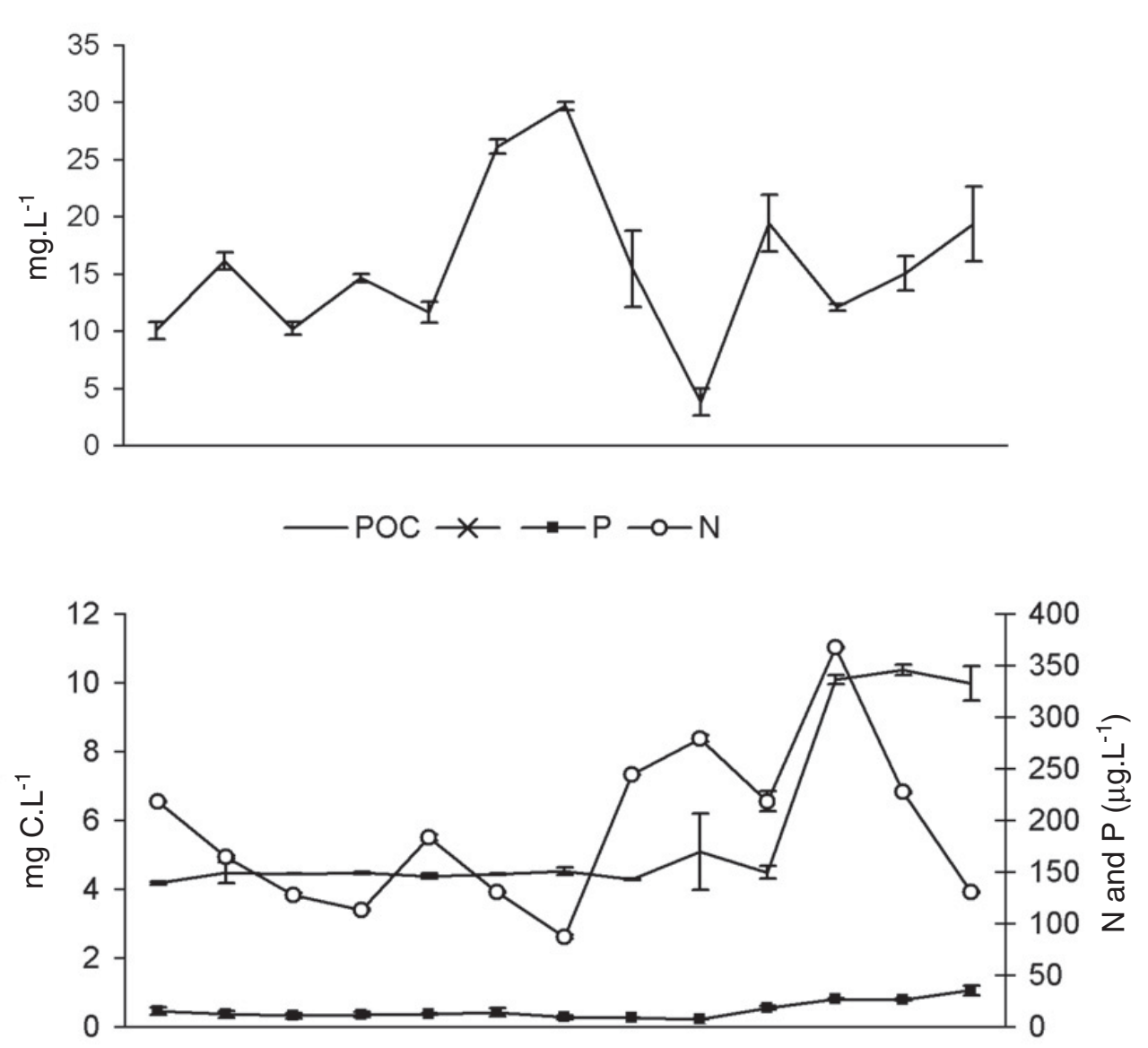

$\rightarrow-C: P \longrightarrow C: N$

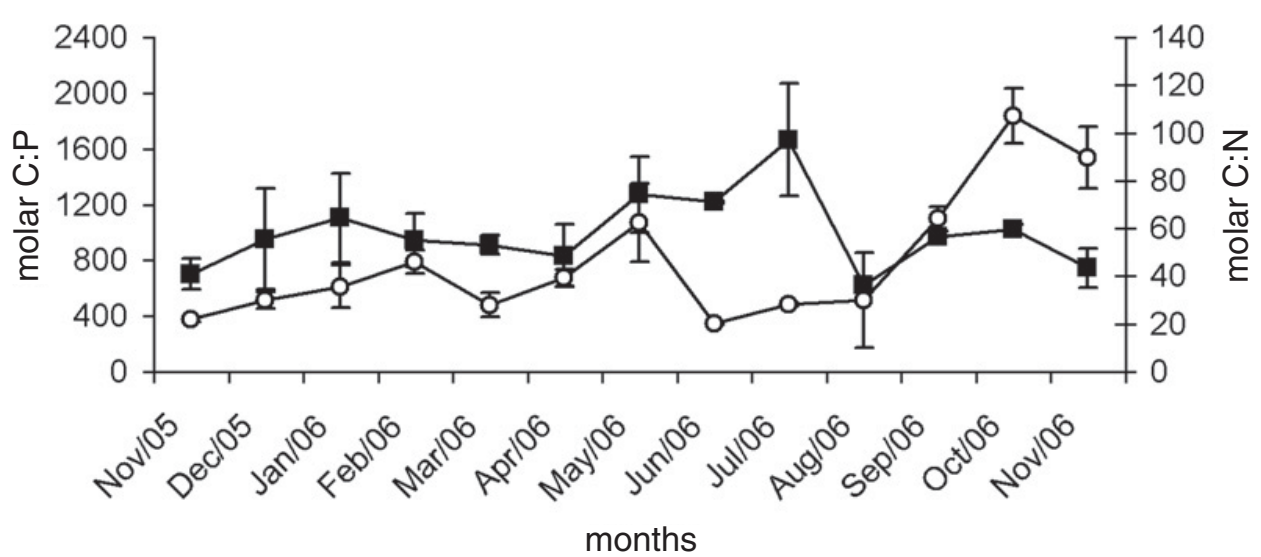

Fig. 1. Mean annual variation $( \pm \mathrm{SD})$ of suspended matter $(\mathrm{SM})$, particulate organic carbon (POC), nitrogen $(\mathrm{N})$, and phosphorus $(\mathrm{P})$ concentrations, and $\mathrm{C}: \mathrm{P}$ and $\mathrm{C}: \mathrm{N}$ molar ratios of seston $\leq 36 \mu \mathrm{m}$ in Camargo Lake.

this species was unable to grow in the seston fraction $>36 \mu \mathrm{m}$.

In Experiment I, M. micrura did not reproduce in the seston fraction $>36 \mu \mathrm{m}$, and its fecundity was higher in the seston plus the green alga compared to the fraction $\leq 36 \mu \mathrm{m} \quad(P=0.002)$ (Fig. 4). A higher fecundity of $B$. longirostris occurred in the seston plus the green alga than in the seston $>36 \mu \mathrm{m}(P=0.04)$. B. longirostris produced a lower average number of eggs $(<1)$ in the larger fraction in Experiment I, and did not reproduce 

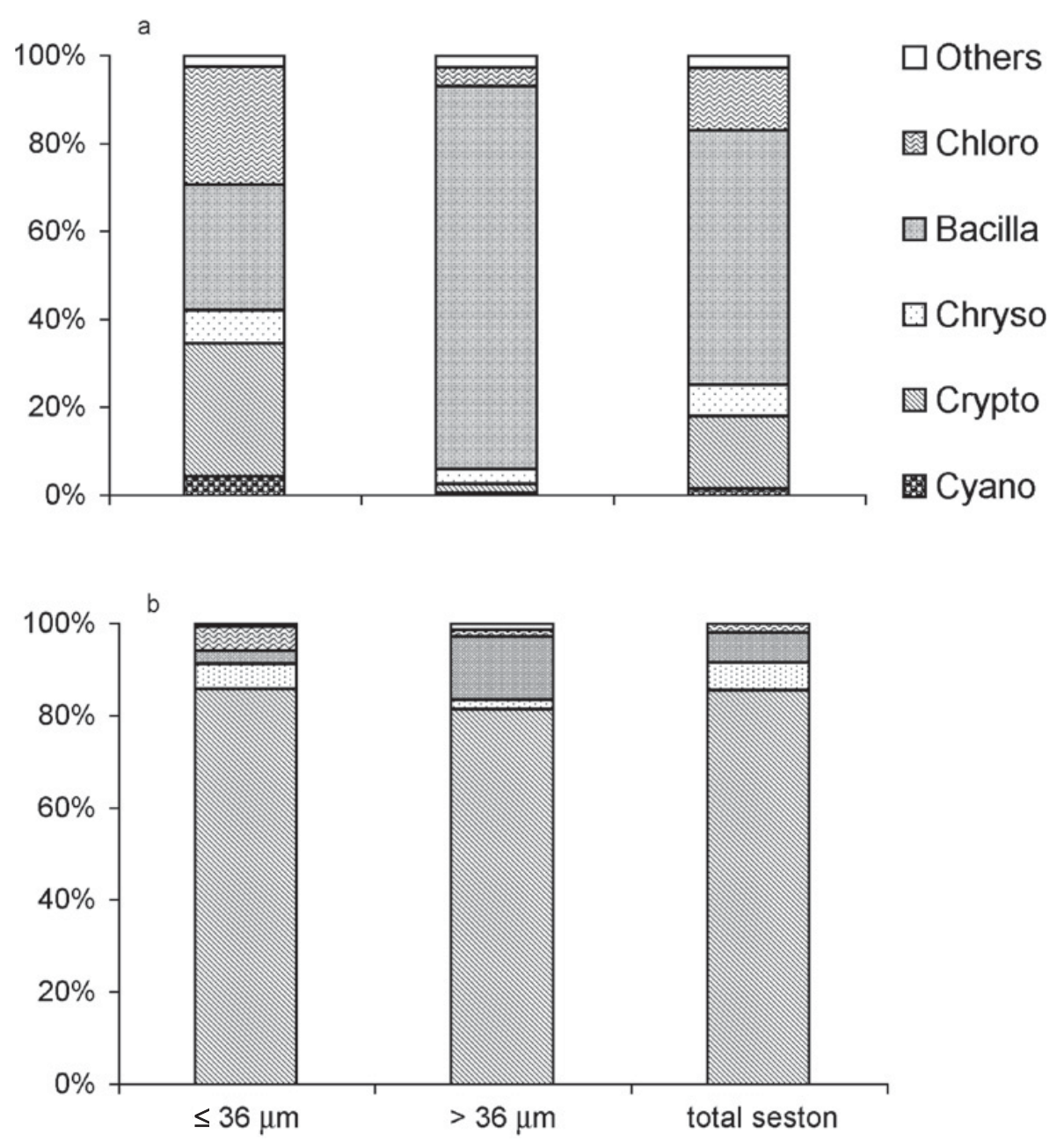

Fig. 2. Relative density of phytoplankton in the total seston and fractions during Experiment I (a) and Experiment II (b).

in this fraction in Experiment II. The fecundity of $M$. minuta was higher in the seston plus the green alga in comparison to the seston fractions $\leq 36 \mu \mathrm{m}$ and $>36 \mu \mathrm{m}$ ( $P=0.001$ and $P=0.0001$, respectively).

\section{Elemental and phytoplankton composition of seston offered to cladocerans}

Comparing the two experiments, $\mathrm{N}$ concentrations were higher in Experiment I in relation to Experiment II (Table 3). In general, POC and P concentrations were lower in the seston $>36 \mu \mathrm{m}$ than in the total seston and the seston $\leq 36 \mu \mathrm{m}$, but carbon was above limiting values. Lower $\mathrm{C}: \mathrm{P}$ ratios were found in the seston $>36 \mu \mathrm{m}$ in both experiments, and in the total seston in Experiment II. $\mathrm{C}: \mathrm{N}$ ratios were lower in Experiment II than in Experiment I. The total seston and the larger fraction were numerically dominated by diatoms in Experiment I, whereas cryptophyceans predominated in the fractions and the total seston in Experiment II (Fig. 2). Fifty-six percent of the seston fraction $\leq 36 \mu \mathrm{m}$, in Experiment $\mathrm{I}$, was composed of algae $\leq 36 \mu \mathrm{m}$, in density, but in biomass, $90 \%$ of the algae were $>36 \mu \mathrm{m}$ (Table 4 ). This can be attributed to contamination by the colonial/ mucilaginous Sphaerocystis schroeterii and the filamentous Urosolenia longiseta (Table 1). The larger seston fraction was numerically dominated by filamentous algae $>36 \mu \mathrm{m}$, such as Urosolenia longiseta and U. eriensis, and by these species and Sphaerocystis schroeterii, in biomass (Tables 1 and 4). In Experiment II, the fraction $\leq 36 \mu \mathrm{m}$ was dominated, in density, by small species (Table 4), but Sphaerocystis schroeterii contributed $32 \%$ to the biomass (Table 1). In the seston fraction $>36 \mu \mathrm{m}$ small algae dominated in density, but the large colonial Botryococcus braunii contributed most to the biomass. The filamentous diatom A. granulata var. granulata contributed a smaller percentage to the biomass of the larger fraction and was underrepresented in the smaller one.

The average algal carbon was ca. 0.42, 0.30, and $0.09 \mathrm{mg} \mathrm{C} . \mathrm{L}^{-1}$ in the total seston, and the seston fractions $\leq 36 \mu \mathrm{m}$ and $>36 \mu \mathrm{m}$, respectively, in Experiment I; and 0.036, 0.044, and $0.11 \mathrm{mg} \mathrm{C.L^{-1 }}$, in Experiment II. These values represented a small contribution of algal carbon to the total POC concentrations: $8.9 \%, 7.9 \%$, and $1.9 \%$, respectively for the total seston and the small and large seston fractions in Experiment $\mathrm{I}$; and $0.85 \%, 1.0 \%$, and $2.6 \%$, respectively in Experiment II. The remaining 
Table 1. Length (GALD), morphological feature, and percentage of density and biomass of the most representative algae species offered to cladocerans during Experiments I and II.

\begin{tabular}{|c|c|c|c|c|}
\hline Species/Group & GALD $(\mu \mathrm{m})$ & Morphological feature & $\%$ Density & $\%$ Biomass \\
\hline \multicolumn{5}{|l|}{ Experiment I } \\
\hline \multicolumn{5}{|l|}{ Total seston } \\
\hline Urosolenia longiseta/Bacillariophyceae & 163.0 & Filamentous & 19.0 & 5.0 \\
\hline U. eriensis/Bacillariophyceae & 133.0 & Filamentous & 18.0 & 7.5 \\
\hline Cyclotela steligera/Bacillariophyceae & 9.5 & Rounded & 8.0 & 2.0 \\
\hline Chroomonas acuta/Cryptophyceae & 9.6 & Oblong & 7.0 & 0.1 \\
\hline Closteriopsis acicularis/Chlorophyceae & 54.0 & Needle-shaped & 5.5 & 0.2 \\
\hline Radiococcus planctonicus/Chlorophyceae & 31.0 & Colonial/mucilaginous & 5.0 & 0.5 \\
\hline Crysococcus sp./Chrysopheceae & 29.0 & Rounded & 5.0 & 0.02 \\
\hline Aulacoseira granulata var. angustissima/Bacillariophyceae & 159.0 & Filamentous & 4.5 & 2.5 \\
\hline C. marsonii/Cryptophyceae & 14.0 & Oblong & 4.0 & 0.4 \\
\hline Cryptomonas sp./Cryptophyceae & 14.0 & Oblong & 3.5 & 0.2 \\
\hline Botryococcus braunii/Chlorophyceae & 118.0 & Colonial & 1.0 & 66.0 \\
\hline Achnanthes minutissima/Bacillariophyceae & 22.0 & Linear & 0.6 & 0.01 \\
\hline \multicolumn{5}{|l|}{$\leq 36 \mu \mathrm{m}$} \\
\hline Chroomonas acuta/Cryptophyceae & 9.6 & Oblong & 16.0 & 0.4 \\
\hline Cryptomonas marsonii/Cryptophyceae & 14.0 & Oblong & 13.0 & 1.6 \\
\hline Urosolenia longiseta/Bacillariophyceae & 133.0 & Elongate/spiny & 12.0 & 6.5 \\
\hline Closteriopsis acicularis/Chlorophyceae & 54.0 & Needle-shaped & 9.5 & 0.6 \\
\hline Radiococcus planctonicus/Chlorophyceae & 31.0 & Colonial/mucilaginous & 7.0 & 1.0 \\
\hline Sphaerocystis schroeterii/Chlorophyceae & 46.0 & Colonial/mucilaginous & 6.5 & 75.0 \\
\hline Cyclotella steligera/Bacillariophyceae & 9.5 & Rounded & 4.0 & 2.0 \\
\hline Crysococcus sp./Chrysophyceae & 7.0 & Rounded & 2.9 & 0.02 \\
\hline Aulacoseira granulata var. angustissima/Bacillariophyceae & 159.0 & Filamentous & 1.8 & 1.6 \\
\hline Cryptomonas sp./Cryptophyceae & 14.0 & Oblong & 1.8 & 0.2 \\
\hline \multicolumn{5}{|l|}{$>36 \mu \mathrm{m}$} \\
\hline Urosolenia eriensis/Bacillariophyceae & 133.0 & Filamentous & 35.5 & 26.0 \\
\hline U. longiseta/Bacillariophyceae & 163.0 & Filamentous & 28.0 & 15.0 \\
\hline Aulacoseira granulata var. angustissima & 159.0 & Filamentous & 9.5 & 9.0 \\
\hline Achnantes minutissima/Bacillariophyceae & 22.0 & Linear & 7.0 & 0.2 \\
\hline Dinobryon bavaricum/Chrysophyceae & 58.0 & Colonial & 2.0 & 3.0 \\
\hline Sphaerocystis schroeterii/Chlorophyceae & 46.0 & Colonial/mucilaginous & 2.0 & 29.0 \\
\hline Chroomonas acuta/Cryptophyceae & 9.6 & Oblong & 2.0 & 0.05 \\
\hline \multicolumn{5}{|l|}{ Experiment II } \\
\hline \multicolumn{5}{|l|}{ Total seston } \\
\hline Cryptomonas spp./Cryptophyceae & 11.6 & Oblong & 45.0 & 40.5 \\
\hline Chroomonas sp./Cryptophyceae & 7.2 & Oblong & 35.5 & 6.0 \\
\hline Mallomonas spp./Chrysophyceae & 26.0 & Flagellate/spiny & 6.0 & 20.0 \\
\hline Aulacoseira distans/Bacillariophyceae & 12.1 & Filamentous & 3.0 & 9.0 \\
\hline C. brasiliensis/Cryptophyceae & 19.0 & Oblong & 1.0 & 1.85 \\
\hline Closteriopsis aciccularis/Chlorophyceae & 54.0 & Needle-shaped & 1.0 & 0.7 \\
\hline Botryococcus braunii/Chlorophyceae & 118.0 & Colonial & 1.0 & 0.7 \\
\hline Cyclotella steligera Bacillariophyceae & 9.5 & Rounded & 1.0 & 4.0 \\
\hline Aulacoseira granulata var. granulata $/$ Bacillariophyceae & 126.0 & Filamentous & 0.4 & 11.0 \\
\hline \multicolumn{5}{|l|}{$\leq 36$ um } \\
\hline Cryptomonas sp./Cryptophyceae & 11.6 & Oblong & 43.0 & 22.0 \\
\hline Chroomonas sp./Cryptophyceae & 7.2 & Oblong & 32.0 & 3.2 \\
\hline Chroomonas acuta/Cryptophyceae & 9.6 & Oblong & 7.0 & 0.7 \\
\hline Mallomonas spp./Chrysophyceae & 26.0 & Flagellate/spiny & 5.0 & 10.0 \\
\hline C. marsonii/Cryptophyceae & 14.0 & Oblong & 3.0 & 22.0 \\
\hline Cyclotella steligera/Bacillariophyceae & 9.5 & Rounded & 2.0 & 3.5 \\
\hline Sphaerocystis schroeterii/Chlorophyceae & 46.0 & Colonial/mucilaginous & 0.6 & 32.0 \\
\hline \multicolumn{5}{|l|}{$>36 \mu \mathrm{m}$} \\
\hline Chroomonas sp./Cryptophyceae & 7.2 & Oblong & 43.0 & 1.0 \\
\hline Cryptomonas spp./Cryptophyceae & 11.6 & Oblong & 38.0 & 4.0 \\
\hline Asterionella formosa $/$ Bacillariophyceae & 80.0 & Coenobic & 5.0 & 0.6 \\
\hline Aulacoseira granulata var. granulata/Bacillariophyceae & 126.0 & Filamentous & 3.0 & 8.0 \\
\hline Aulacoseira granulata var. angustissima/Bacillariophyceae & 159.0 & Filamentous & 1.5 & 1.0 \\
\hline A. distans/Bacillariophyceae & 21.0 & Filamentous & 1.0 & 0.3 \\
\hline Botryococcus braunii/Chlorophyceae & 118.0 & Colonial & 0.7 & 54.0 \\
\hline
\end{tabular}


Table 2. Age at first reproduction (days), total neonates (number of produced neonates), fecundity (number neonates/clutch), maximum clutch size (number of neonates), longevity (days), and intrinsic rate of natural increase $(r$ ) (average \pm SD) of cladocerans grown at $17^{\circ} \mathrm{C}, 23^{\circ} \mathrm{C}$, and $27^{\circ} \mathrm{C}$. Different letters indicate significant differences.

\begin{tabular}{|c|c|c|c|c|}
\hline & $17^{\circ} \mathrm{C}$ & $23^{\circ} \mathrm{C}$ & $27^{\circ} \mathrm{C}$ & $P$ \\
\hline \multicolumn{5}{|l|}{ M. micrura } \\
\hline Age at first reproduction & $6.5 \pm 0.5(\mathrm{a})$ & $4.5 \pm 0.8(b)$ & $4.0 \pm 0.0(b)$ & 0.002 \\
\hline Total neonates & $24.5 \pm 2.4$ (a) & $53.0 \pm 17.0(\mathrm{~b})$ & $42.5 \pm 17.7(\mathrm{ab})$ & 0.048 \\
\hline Fecundity & $6.0 \pm 0.6(a)$ & $6.0 \pm 1.0$ (a) & $4.5 \pm 1.4(\mathrm{a})$ & 0.140 \\
\hline Maximum clutch size & $8.0 \pm 1.4(\mathrm{a})$ & $8.0 \pm 2.5(\mathrm{a})$ & $7.3 \pm 2.1(\mathrm{a})$ & 0.920 \\
\hline Longevity & $24.0 \pm 4.0(\mathrm{a})$ & $24.0 \pm 6.0(\mathrm{a})$ & $12.0 \pm 4.0(\mathrm{~b})$ & 0.020 \\
\hline$r$ & 0.12 (a) & $0.20(\mathrm{a})$ & $0.43(\mathrm{~b})$ & $<0.05$ \\
\hline \multicolumn{5}{|l|}{ D. ambigua } \\
\hline Age at first reproduction & $6.0 \pm 0.5(a)$ & $4.7 \pm 0.7(b)$ & $3.7 \pm 0.7(\mathrm{c})$ & 0.000 \\
\hline Total neonates & $70.0 \pm 33.0(\mathrm{a})$ & $87.0 \pm 44.0$ (a) & $143.0 \pm 19.0(b)$ & 0.000 \\
\hline Fecundity & $9.1 \pm 3.6(\mathrm{a})$ & $9.0 \pm 2.0$ (a) & $9.0 \pm 0.9$ (a) & 0.985 \\
\hline Maximum clutch size & $14.2 \pm 6.0(\mathrm{a})$ & $14.5 \pm 4.5$ (a) & $15.7 \pm 2.0$ (a) & 0.725 \\
\hline Longevity & $33.0 \pm 2.0$ (a) & $31.0 \pm 2.0(\mathrm{a})$ & $31.5 \pm 1.0(\mathrm{a})$ & 0.480 \\
\hline$r$ & 0.14 (a) & $0.23(\mathrm{a})$ & $0.25(\mathrm{~b})$ & $<0.05$ \\
\hline \multicolumn{5}{|l|}{ B. longirostris } \\
\hline Age at first reproduction & - & $4.0 \pm 0.4(\mathrm{a})$ & $3.0 \pm 0.0(b)$ & 0.000 \\
\hline Total neonates & 0.0 & $25.0 \pm 12.0$ (a) & $14.5 \pm 1.7$ (a) & 0.130 \\
\hline Fecundity & 0.0 & $3.0 \pm 1.0$ (a) & $2.2 \pm 1.0(\mathrm{a})$ & 0.340 \\
\hline Maximum clutch size & 0.0 & $4.7 \pm 2.0(\mathrm{a})$ & $3.8 \pm 1.2(\mathrm{a})$ & 0.370 \\
\hline Longevity & $12.0 \pm 4.8$ (a) & $20.0 \pm 7.0(\mathrm{~b})$ & $8.00 \pm 3.0$ (a) & 0.000 \\
\hline$r$ & - & 0.20 (a) & $0.27(\mathrm{~b})$ & $<0.05$ \\
\hline
\end{tabular}

POC was mostly composed of detritus, bacteria, and microzooplankton.

\section{Discussion}

\section{Effects of temperature on cladocerans}

Daphnia ambigua, Moina micrura, and Bosmina longirostris from Lake Camargo showed a better performance at the highest temperature in the experiments. The significantly higher intrinsic rate of natural increase $(r)$ at $27^{\circ} \mathrm{C}$ was, probably, mostly influenced by a shorter time for the onset of reproduction at this temperature. $B$. longirostris experienced a stronger negative effect at the lowest temperature, which precluded its reproduction.

The response of cladocerans to experiments may differ in populations originating from different water bodies, but a better performance has been generally found at the highest temperature tested (Rocha and MatsumuraTundisi, 1990; Gordo et al., 1994; Bunioto and Arcifa, 2007). Growth and reproduction of cladocerans are so dependent on temperature that constraints of food quality can be lower at higher temperatures (Masclaux et al., 2009).

The significantly shorter longevity of $M$. micrura and $B$. longirostris at the highest temperature in the present study, is consistent with observations from other studies (Rietzler, 1998; Benider et al., 2002). The longevity varied among the cladocerans, with the smallest species, $B$. longirostris, showing a shorter lifespan than the other two species at all three temperatures. The similar-sized species D. ambigua and M. micrura showed different longevities, with a shorter lifespan for $M$. micrura ( $\sim 12$ days). This result is in accordance with Murugan (1975) and Díaz-Castro and Hardy (1998), but is double that found in other studies (Jayatunga, 1986; SipaúbaTavares and Bachion, 2002; Sarma et al., 2005). Because of the greater longevity found in our experiments than in other studies (Rocha and Matsumura-Tundisi, 1990; Bunioto and Arcifa, 2007), D. ambigua produced almost four times more neonates per female.

\section{Influence of food size, morphological features and mineral content of sestonic algae}

The contribution of phytoplankton to the total sestonic $\mathrm{C}$ in lakes is usually low, less than $25 \%$, rarely exceeding $40 \%$ (Hessen et al., 2003). In our experiments, algal carbon comprised a much lower proportion of the total seston available to cladocerans $(0.85-8.9 \%)$, and detritus, bacteria, and microzooplankton contributed a larger proportion. Planktonic bacteria and detritus can be dietary items for zooplankton (Hessen et al., 1990; Hart et al., 2000), and the non-algal sestonic component is likely a food source for cladocerans in Lake Camargo. The three species differ in their ability to use carbon sources other than algae, just as they differ in their ability to handle inedible algae, which could explain the differences in growth and reproduction that we observed.

Food limitation by carbon during Experiment I is unlikely, considering that sestonic and algal carbon 


\section{M. micrura}
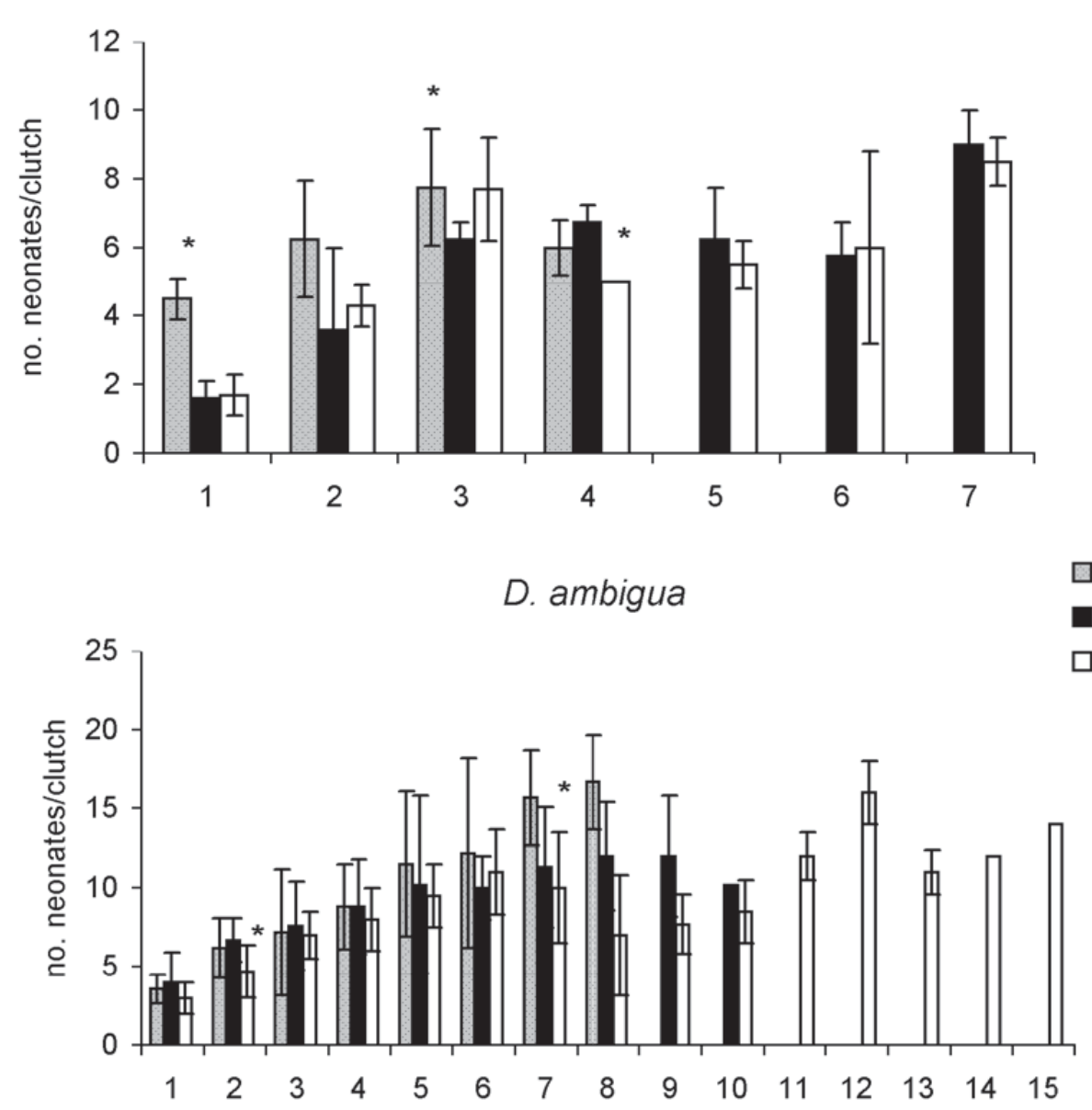

\section{B. longirostris}

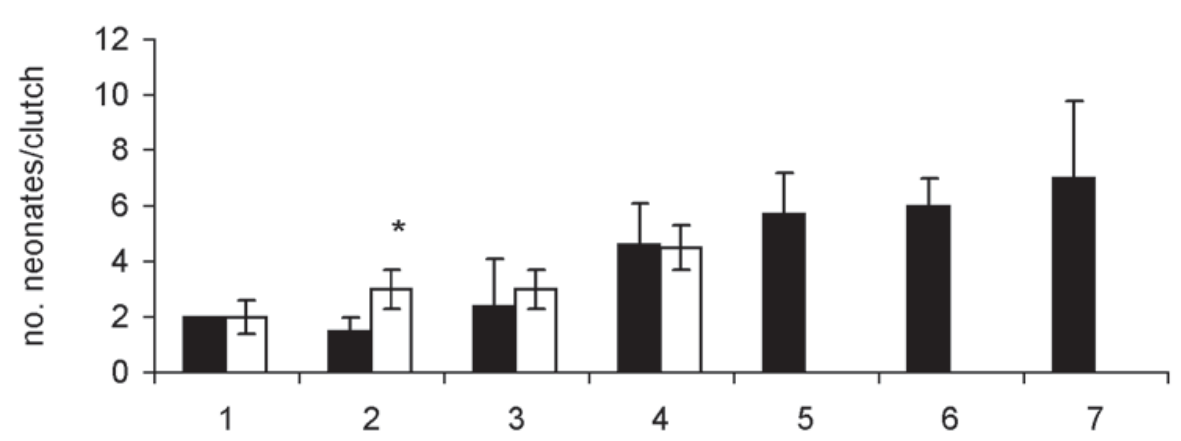

Fig. 3. Clutch size of cladocerans at the different temperatures tested. Mean \pm SD; asterisk indicates a significant difference.

concentrations exceeded the threshold food concentrations (TFC) commonly reported for cladocerans (0.005-0.14 mg C. $\mathrm{L}^{-1}$ to a maximum of $0.31 \mathrm{mg} \mathrm{C.L^{-1 }}$, converting dry weight data reviewed by Sarma et al. (2005) into $\mathrm{C}$ ) and specifically for tropical cladocerans

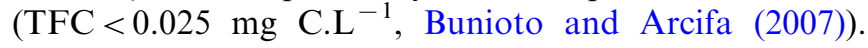
Although POC concentrations were high in Experiment II and similar to those of Experiment I, the contribution of algae to the sestonic carbon was lower. The estimated algal

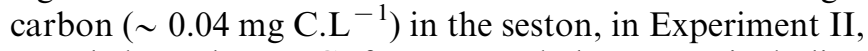
was below the TFC for most cladocerans, including species of Moina (Sarma et al., 2005). Although the values were above the TFC estimated for two tropical cladocerans (Bunioto and Arcifa, 2007), these authors found that concentrations of algal carbon lower than $0.10 \mathrm{mg} \mathrm{C.L}{ }^{-1}$ can constrain their growth and reproduction. 

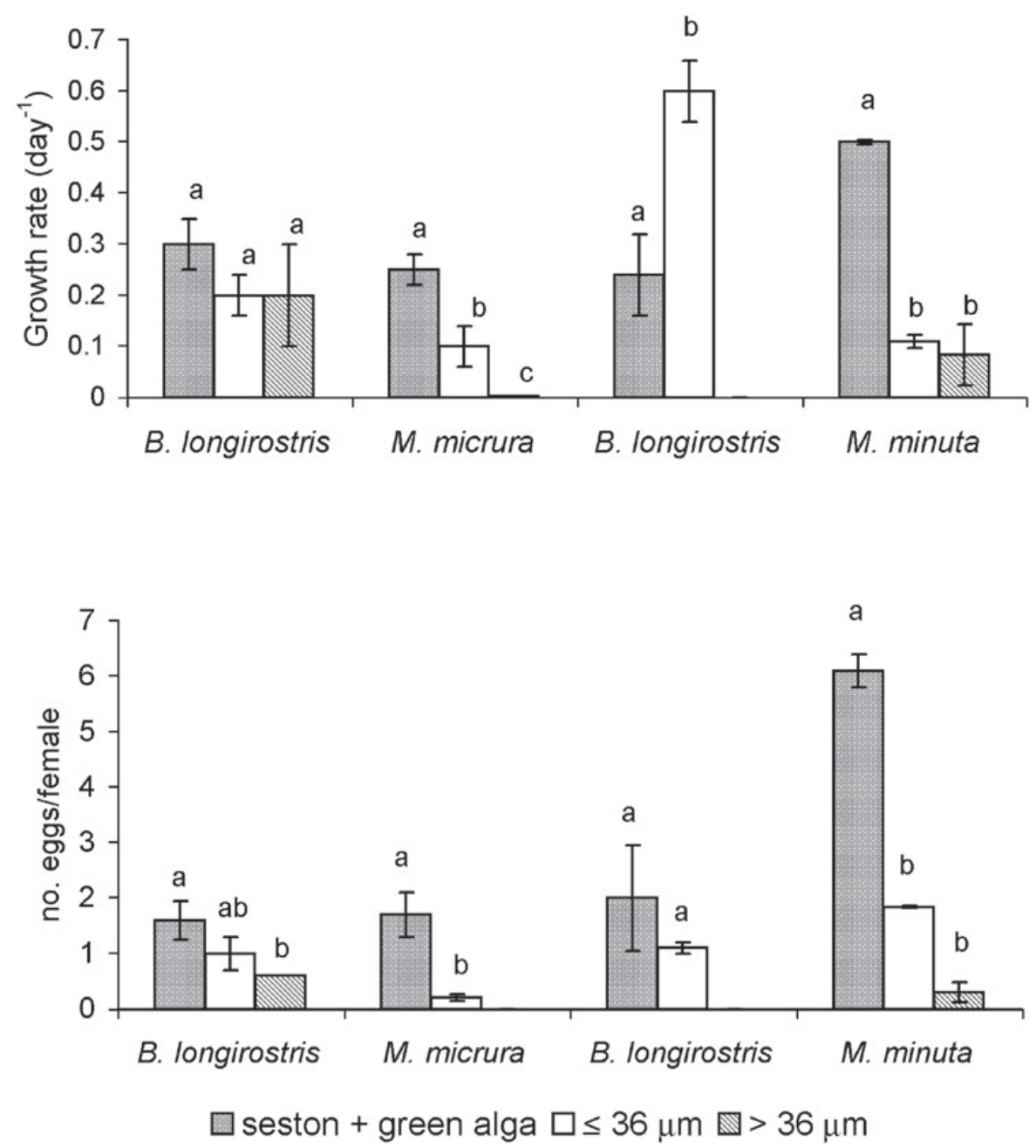

Fig. 4. Growth rates (a) and fecundity (b) (mean \pm SD) of Bosmina longirostris, Moina micrura, and M. minuta in Experiments I and II. Different letters above bars indicate significant differences.

Table 3. Mean values $( \pm$ SD) of particulate organic carbon $(P O C)$, phosphorus $(P)$, nitrogen $(N), C: P$ and $C: N$ ratios (molar) from seston fractions $\leq 36 \mu \mathrm{m}$ and $>36 \mu \mathrm{m}$ and total seston used as food in the growth experiments. na $=$ not analyzed.

\begin{tabular}{llccccc}
\hline Experiment & Food & POC $\left(\mathrm{mg} . \mathrm{L}^{-1}\right)$ & $\mathrm{P}\left(\mu \mathrm{g} . \mathrm{L}^{-1}\right)$ & $\mathrm{N}\left(\mathrm{mg} . \mathrm{L}^{-1}\right)$ & $\mathrm{C}: \mathrm{P}$ & $\mathrm{C}: \mathrm{N}$ \\
\hline $\mathrm{I}$ & Total seston & $4.70 \pm 0.10$ & $10.80 \pm 3.10$ & $0.35 \pm 0.00$ & $1216.50 \pm 321.80$ & $78.60 \pm 2.00$ \\
& Seston $\leq 36 \mu \mathrm{m}$ & $3.80 \pm 0.01$ & $6.00 \pm 0.02$ & $0.16 \pm 0.02$ & $1682.50 \pm 3.50$ & $74.60 \pm 5.80$ \\
& Seston $>36 \mu \mathrm{m}$ & $1.40 \pm 0.07$ & $7.00 \pm 0.04$ & na & $557.00 \pm 0.03$ & na \\
& & & & & \\
II & Total seston & $4.20 \pm 0.30$ & $13.50 \pm 0.35$ & $0.08 \pm 0.00$ & $883.00 \pm 39.70$ & $65.50 \pm 12.00$ \\
& Seston $\leq 36 \mu \mathrm{m}$ & $4.40 \pm 0.07$ & $13.00 \pm 0.30$ & $0.10 \pm 0.00$ & $903.00 \pm 3.70$ & $45.70 \pm 0.80$ \\
& Seston $>36 \mu \mathrm{m}$ & $1.40 \pm 0.00$ & $7.00 \pm 0.00$ & $0.12 \pm 0.00$ & $543.00 \pm 2.70$ & $13.20 \pm 0.03$ \\
\hline
\end{tabular}

Table 4. Contribution in percentage of density and biomass (in brackets) of algae $\leq 36 \mu \mathrm{m}$ and $>36 \mu \mathrm{m}$ to the total seston and seston fractions during the Experiments I and II.

\begin{tabular}{|c|c|c|c|c|c|c|}
\hline \multirow[b]{2}{*}{ Treatment } & \multicolumn{3}{|c|}{ Experiment I } & \multicolumn{3}{|c|}{ Experiment II } \\
\hline & Total seston & $\leq 36 \mu \mathrm{m}$ & $>36 \mu \mathrm{m}$ & Total seston & $\leq 36 \mu \mathrm{m}$ & $>36 \mu \mathrm{m}$ \\
\hline$\overline{\text { Algae } \leq 36 \mu \mathrm{m}}$ & $45.0(13.5)$ & $56.0(10.0)$ & $12.0(2.3)$ & $90.0(60.5)$ & $87.0(40.0)$ & $83.0(7.0)$ \\
\hline Algae $>36 \mu \mathrm{m}$ & $55.0(86.5)$ & $44.0(90.0)$ & $88.0(97.7)$ & $10.0(39.5)$ & $13.0(60.0)$ & $17.0(93.0)$ \\
\hline
\end{tabular}


Limiting values of sestonic $\mathrm{C}: \mathrm{P}$ and $\mathrm{C}: \mathrm{N}$ ratios have not yet been established in the tropics. Based on the generally accepted limits for temperate lakes, C:P and $\mathrm{C}: \mathrm{N}$ ratios were limiting in Lake Camargo. According to Hessen's (2008) conceptual model for C and P-limitation for Daphnia, particulate $\mathrm{P}$ levels in Lake Camargo are not low. However, because particulate $\mathrm{C}$ is very high in this lake, the levels fall in the area of $\mathrm{C}$-saturation and P-limitation (Hessen, 2008). When detritus contribution to the sestonic carbon is high, $\mathrm{C}: \mathrm{P}$ ratios may be distorted and consequently do not represent the actual phytoplankton ratios (Tett et al., 1985 in Hecky et al., 1993). Frequent circulation and resuspension of sediment in Lake Camargo and a smaller contribution of suspended matter from the river (Henry, 2009) drive detritus into the water column, increasing the POC and $\mathrm{C}: \mathrm{P}$ and $\mathrm{C}: \mathrm{N}$ ratios.

In our study, we found no clear evidence that decreased $\mathrm{C}: \mathrm{P}$ ratios, after the addition of $S$. spinosus to seston $(C: P$ ratios decreased to $224 \pm 1.20$ and $544 \pm 10.4$ in Experiments I and II, respectively), were responsible for the better performance of Moina micrura and M. minuta. If lower $\mathrm{C}: \mathrm{P}$ ratios were the reason for the enhanced growth and reproduction, the seston fraction $>36 \mu \mathrm{m}$ should be equally more suitable for cladocerans (C:P 557 and 543, respectively in Experiments I and II). However, since a positive effect of the larger fraction was not detected in the experiments, other features of the food are likely more important for cladocerans' performance. The addition of the green alga to the seston could improve the edibility of the food, because its size, form, and taste are suitable for cladocerans.

The contamination of the seston in both fractions indicates that fractionation through a net is not entirely efficient for separating algae by size. Consequently, a detailed analysis of the phytoplankton contained in the fractions offered to cladocerans is necessary, as discussed by Fileto et al. (2004) and adopted in our study. Despite the contribution of small algae, the larger seston fraction caused more negative effects on cladocerans than the smaller one, which might be explained by a higher biomass of inedible algae in the larger fraction.

In addition to size, other algae features can constrain the development of cladocerans, such as resistance to digestion (Sterner and Hessen, 1994), gelatinous sheaths and the presence of spines (Lampert, 1987), and colonial or filamentous structures (Kurmayer, 2000). The composition of the dominant algae in the seston fractions of our experiments probably determined the cladocerans' performance in the experiments. Thus, large diatoms (Urosolenia eriensis and $U$. longiseta) and the mucilaginous chlorophycean $S$. schroterii present in the seston $>36 \mu \mathrm{m}$ were inedible for cladocerans, in Experiment I. The larger seston fraction in Experiment II offered lower food quality owing to a high biomass of the large colonial chlorophycean Botryococcus braunii, which contains oil and mucilage, mixed with small edible cryptophyceans. Our findings are consistent with another study that reported nanoplankton as the best food fraction for small tropical cladoceran species (Fileto et al., 2004).

\section{Linking field data and experiments}

Small cladoceran species such as bosminids (Bosmina longirostris and Bosminopsis deitersi) dominate the zooplankton of Lake Camargo, followed by sidids (Diaphanosoma birgei) and small daphnids (Ceriodaphnia cornuta) (Panarelli, 2004). Species of moinids (Moina minuta and $M$. micrura) can reach high abundances, whereas larger daphnids (Daphnia ambigua and D. gessneri) are rare.

Bosmina longirostris, which is most abundant during the warm-wet season, can be replaced by Bosminopsis deitersi during the cool-dry period (Panarelli, 2004). Our results with different temperatures are in accordance with these observations, since $B$. longirostris was more sensitive to low temperature, being unable to reproduce at $17^{\circ} \mathrm{C}$ (winter temperature). It seems that the species is more adapted to higher temperatures, especially to the intermediate one $\left(23^{\circ} \mathrm{C}\right)$. Although the other cladocerans (Moina micrura and Daphnia ambigua) outperformed Bosmina longirostris in the experiments, in the field this species is more successful and can reach higher densities.

Lake Camargo, which experiences daily circulation, influence of the river, wide fluctuations in water level (Henry, 2005), and with the sestonic carbon largely composed of detritus and non-algal sources, is a selective environment for cladocerans. Which are the advantages of Bosmina longirostris in this lake, where densities can range from 100 to 500 ind. $\mathrm{L}^{-1}$ (Panarelli, 2004)? Some reasons can be enumerated: it is a fast-growing species, which benefits from short suitable periods in terms of food and temperature, and is less sensitive than other larger cladocerans to the high amount of sestonic detritus and suspended inorganic particles. The latter statement can be supported by the suggestion that Bosmina is a highly selective feeder (DeMott, 1982) and is less sensitive to high seston concentrations (Acharya et al., 2006).

\section{Conclusions}

Lake Camargo is a special kind of water body, since it is influenced by a river and is therefore strongly affected by hydrological pulses (Henry, 2005). In this disturbed environment, phytoplankton may remain in a successional stage, dominated by small and fast-growing species such as cryptophyceans and diatoms, some of them resuspended from the bottom (Henry et al., 2006; Granado et al., 2009). Detritus and sediment resuspended by the daily circulation, in addition to the small amounts contributed by the river, decrease light penetration, benefiting some planktonic groups such as cryptophyceans (Henry et al., 2006). These small algae are edible and should favor cladoceran populations, but herbivores may be constrained by the large amounts of other carbon sources and inorganic 
particles in the seston. In this unstable environment, zooplankton species might be adapted to survive under food limitation. Carbon limitation is probable, at least during some periods of the year, since the sestonic carbon is predominantly composed of low-quality or unsuitable foods for most herbivores. Algae size, shape, and other features can constrain herbivores, contributing to decrease carbon uptake, and interfering with food processing, thus increasing their energy expenditures. Any effect of mineral limitation is likely smaller than that of carbon (energy) limitation. Furthermore, sestonic $\mathrm{C}: \mathrm{P}$ and $\mathrm{C}: \mathrm{N}$ ratios can be distorted by the large amount of carbon sources other than algae, so that high values do not necessarily indicate sestonic stoichiometric limitation for herbivores. Although temperature fluctuates within relatively narrow limits during the year, it can influence the development of cladoceran populations.

Acknowledgements. We thank Fapesp (São Paulo State Foundation for Research Support) for a grant to C. Fileto (2005/50278-9). We are grateful to the personnel of the Limnology Laboratory for their help in the field, and to J. W. Reid for linguistic improvement.

\section{References}

Acharya K., Kyle M. and Elser J.J., 2004. Effects of stoichiometric dietary mixing on Daphnia growth and reproduction. Oecologia, 138, 333-340.

Acharya K., Bukaveckas P.A., Jack J.D., Kyle M. and Elser J., 2006. Consumer growth linked to diet and RNA-P stoichiometry: Response of Bosmina to variation in riverine food resources. Limnol. Oceanogr., 51, 1859-1869.

Andersen D.H. and Benke A.C., 1994. Growth and reproduction of the cladoceran Ceriodaphnia dubia from a forested floodplain swamp. Limnol. Oceanogr., 39, 1517-1527.

Benider A., Tifnout A. and Pourriot R., 2002. Growth of Moina macrocopa (Straus 1820) (Crustacea, Cladocera): influence of trophic conditions, population density and temperature. Hydrobiologia, 468, 1-11.

Bottrell H.H., 1975. The relation between temperature and duration of egg development in some epiphytic Cladocera and Copepoda from the River Thames, Reading, with a discussion of temperature functions. Oecologia, 18, 63-84.

Bunioto T.C. and Arcifa M.S., 2007. Effects of food limitation and temperature on cladocerans from a tropical Brazilian lake. Aquat. Ecol., 41, 569-578.

Burns C.W., 1968. The relationship between body size of filterfeeding Cladocera and the maximum size of particles ingested. Limnol. Oceanogr., 13, 675-678.

Casanova S.M.C. and Henry R., 2004. Longitudinal distribution of Copepoda populations in the transition zone of Paranapanema River and Jurumirim Reservoir (São Paulo, Brazil) and interchange with two lateral lakes. Braz. J. Biol., 64, 11-26.

Choueri R.B., Bonecker C.C. and Dias J.D., 2005. Spatial and temporal density variation of microcrustacean assemblages in different systems of the upper Paraná River floodplain (PR/MSBrazil). Acta Sci. Biol., 27, 243-250.

Cole G.A., 1979. Textbook of Limnology, The C.V. Mosby Company, Saint Louis.

De Nadai R. and Henry R., 2009. Temporary fragmentation of a marginal lake and its effects on zooplankton community structure and organization. Braz. J. Biol., 69, 819-835.

DeMott W.R., 1982. Feeding selectivities and relative ingestion rates of Daphnia and Bosmina. Limnol. Oceanogr., 27, 518-527.

Díaz-Castro J.G. and Hardy E.R., 1998. Life history of Moina micrura (Kurz) fed with three algae species, in the laboratory. Amazoniana, XV, 25-34.

Fileto C., Arcifa M.S., Ferrão-Filho A.S. and Silva L.H.S., 2004. Influence of phytoplankton fractions on growth and reproduction of tropical cladocerans. Aquat. Ecol., 38, 503-514.

Gordo T., Lubian L.M. and Canavate J.P., 1994. Influence of temperature on growth, reproduction and longevity of Moina salina Daday, 1888 (Cladocera, Moinidae). J. Plankton Res., $11,1513-1523$.

Gotelli N.J., 1995. A primer of Ecology, Sinauer Associates, Inc. Publishers, Sounderland.

Granado D.C. and Henry R., 2008. The influence of the hydrologic pulse on the water physical and chemical variables of lateral lakes with different connections levels to Paranapanema River in the mouth zone at Jurumirim reservoir (São Paulo, Brazil). Acta Limnol. Bras., 20, 265-275.

Granado D.C., Henry R. and Tucci A., 2009. Influência da variação do nível hidrométrico na comunidade fitoplanctônica do Rio Paranapanema e de uma lagoa marginal na zona de desembocadura na Represa de Jurumirim (SP). Hoehnea, 36, 113-129.

Gulati R.D. and DeMott W.R., 1997. The role of food quality for zooplankton: remarks on the state-of-the-art, perspectives and priorities. Freshwat. Biol., 38, 753-768.

Hart D.R., Stone L. and Berman T., 2000. Seasonal dynamics of the Lake Kinneret food web: The importance of the microbial loop. Limnol. Oceanogr., 45, 350-361.

Hecky R.E., Campbell P. and Hendzel L.L., 1993. The stoichiometry of carbon, nitrogen, and phosphorus in particulate matter of lakes and oceans. Limnol. Oceanogr., $38,709-724$.

Henry R., 2005. The connectivity of the Paranapanema River with two lateral lakes in its mouth zone into the Jurumirim Reservoir. Acta Limnol. Bras., 17, 57-69.

Henry R., 2009. Annual changes in sediment entrapment efficiency in lakes lateral to a river (Paranapanema River, São Paulo, Brazil). Acta Limnol. Bras., 21, 25-34.

Henry R., Ushinohama E. and Ferreira R.M.R., 2006. O fitoplâncton em três lagoas e no Rio Paranapanema na zona de sua desembocadura na Represa de Jurumirim durante um período prolongado de seca. Rev. Brasil. Bot., 29, 399-414.

Hessen D.O., 2006. Determinants of seston C:P-ratio in lakes. Freshwat. Biol., 51, 1560-1569.

Hessen D.O., 2008. Efficiency, energy and stoichiometry in pelagic food webs; reciprocal roles of food quality and food quantity. Freshwat. Rev., 1, 43-57.

Hessen D.O., Andersen T. and Lyche A., 1990. Carbon metabolism in a humic lake: Pool sizes and cycling through zooplankton. Limnol. Oceanogr., 35, 84-99. 
Hessen D.O., Andersen T., Brettum P. and Faafeng B.A., 2003. Phytoplankton contribution to seston mass elemental ratios in lakes: implications for zooplankton nutrition. Limnol. Oceanogr., 48, 1289-1296.

Jayatunga Y.N.A., 1986. The influence of food and temperature on the life cycle characteristics of tropical cladoceran species from Kalewewa Reservoir, Sri Lanka. Ph.D. Thesis, University of London, London.

Kurmayer R., 2000. Nutritive vs. interfering effects of Anabaena on Daphnia and Ceriodaphnia. Verh. Internat. Verein. Limnol., 27, 1-4.

Lampert W., 1987. Laboratory studies on zooplanktoncyanobacteria interactions. New Zeal. J. Mar. Freshwat. Res., 21, 483-490.

Lennon J.T., Smith V.H. and Williams K., 2001. Influence of temperature on exotic Daphnia lumholtzi and implications for invasion success. J. Plankton Res., 23, 425-434.

Luciano S.C. and Henry R., 1998. Biomass of Eichhornia azurea Kunth. and Brachiaria arrecta Stent. in lower Taquari river, Jurumirim Reservoir, São Paulo, Brazil. Verh. Internat. Verein. Limnol., 26, 1857-1861.

Mackareth F.J.H., Heron J. and Talling J.F., 1978. Water Analysis: Some Revised Methods for Limnologists, Scientific Publication $\mathrm{n}^{\circ}$ 36, Freshwater Biological Association, Cumbria and Dorser.

Martins G.M. and Henry R., 2004. Composição e abundância do zooplâncton em três lagoas laterais ao rio Paranapanema na zona de sua desembocadura na Represa de Jurumirim (São Paulo). In: Chellapa N.T., Chellapa S. and Passavante J.Z.O. (eds.), Ecologia Aquática Tropical, Natal, 53-72.

Martins-Creuzburg D., Sperfeld E. and Wacker A., 2009. Colimitation of a freshwater herbivore by sterols and polyunsaturated fatty acids. Proc. Soc. B., 276, 1805-1814.

Masclaux H., Bec A., Kainz M.J., Desvilettes C., Jouve L. and Bourdier G., 2009. Combined effects of food quality and temperature on somatic growth and reproduction of two freshwater cladocerans. Limnol. Oceanogr., 54, 1323-1332.

Moschini-Carlos V., Pompeo M.L.M. and Henry R., 1999. Dinâmica da comunidade perifítica na zona de desembocadura do Rio Paranapanema, Represa de Jurumirim, SP. In: Henry R. (ed.), Ecologia de Reservatórios: estrutura, função e aspectos sociais, Ed. Fapesp/Fundibio, Botucatu, 713-734.

Murphy J. and Riley J.P., 1962. A modified single solution method for the determination of phosphate in natural waters. Anal. Chim. Acta, 27, 31-36.

Murugan N., 1975. Egg production, development and growth in Moina micrura Kurz (1874) (Cladocera: Moinidae). Freshwat. Biol., 5, 245-250.

Padisák J. and Reynolds C.S., 2003. Shallow lakes: the absolute, the relative, the functional and the pragmatic. Hydrobiologia, $506,1-11$.

Panarelli E.A., 2004. Flutuações mensais da comunidade zooplanctônica e dinâmica das populações de Cladocera em lagoas marginais, na região de transição Rio ParanapanemaRepresa de Jurumirim (SP). Ph.D. Thesis, Botucatu, Unesp, Brazil.
Panarelli E.A., Casanova S.M.C., Nogueira M.G., Mitsuka P.M. and Henry R., 2003. A comunidade zooplanctônica ao longo de gradientes longitudinais no Rio Paranapanema/Represa de Jurumirim (São Paulo, Brasil). In: Henry R. (ed.), Ecótonos nas interfaces dos ecossistemas aquáticos, Rima Editora, São Carlos, 129-160.

Ravet J.L. and Brett M.T., 2006. Phytoplankton essential fatty acid and phosphorus content constraints on Daphnia somatic growth and reproduction. Limnol. Oceanogr., 51, 2438-2452.

Rietzler A.C., 1998. Tempo de desenvolvimento, reprodução e longevidade de Diaphanosoma birgei Korinek e Ceriodaphnia silvestrii Daday em condições naturais de alimentação. Anais VIII Sem. Reg. Ecol., 8, 1159-1171.

Rocha O. and Matsumura-Tundisi T., 1990. Growth rate, longevity and reproductive performance of Daphnia laevis Birge, D. gessneri Herbst and D. ambigua Scourfield in laboratory cultures. Braz. J. Biol., 50, 915-921.

Sarma S.S.S., Nandini S. and Gulati R.D., 2005. Life history of cladocerans: comparisons of tropical and temperate taxa. Hydrobiologia, 542, 315-333.

Scheffer M., 2004. Ecology of Shallow Lakes - Population and Community Biology Series, Kluwer Academic Publishers.

Seidendorf B., Meier N., Petrusek A., Boersma M., Streit B. and Schwenk K., 2010. Sensivity of Daphnia species to phosphorus-deficient diets. Oecologia, 162, 349-357.

Sipaúba-Tavares L.H. and Bachion M.A., 2002. Influence of dietary habits (algae + supplement) on laboratory population growth and development of two species of Cladocera, Moina micrura and Diaphanosoma birgei. Braz. J. Biol., 62, $12-15$.

Stemberger R.S., 1981. A general approach to the culture of planktonic rotifers. Can. J. Fish. Aquat. Sci., 38, 721-724.

Sterner R.W. and Hessen D.O., 1994. Algal nutrient limitation and the nutrition of aquatic herbivores. Annu. Rev. Ecol. Evol. Syst., 25, 1-29.

Strickland J.D.H. and Parsons T.R., 1972. A Practical Handbook of Seawater Analysis, Fisheries Research Board of Canada, Bulletin 167.

Talling J.F. and Lemoalle J., 1998. Ecological dynamics of tropical inland waters, Cambridge University Press.

Tett A., Heaney S.I. and Droop M.R., 1985. The Redfield ratio and phytoplankton growth rate. J. Mar. Biol. Assoc. UK, 65, 487-504.

Utermöhl V., 1958. Zur Vervollkommung der quantitativen Phytoplankton-Methodik. Mitt. Int. Verein. Theor. Angew. Limnol., 9, 1-38.

Vanni M.J., 1987. Effects of food availability and fish predation on a zooplankton community. Ecol. Monogr., 57, 61-68.

Vijverberg J., 1980. Effect of temperature in laboratory studies on development and growth of cladocera and copepoda from Tjeukemeer, the Netherlands. Freshwat. Biol., 10, 317-340.

Vollenweider R.A., 1974. Primary Production in Aquatic Environments, Blackwell Scientific Publications, Osney Mead, Oxford. 